\title{
The Future of Business Services in the Age of Ubiquitous Computing
}

\section{ユビキタスコンピューティング時代における ビジネスサービスの未来}

\section{Andrew Fano and Anatole Gershman}

\author{
ビジネスと顧客の関係のとらえ方を再定義する.
}

\begin{abstract}
概要: ユビキタスコンピューティングによって私たちが技術と共にくらす方法 は変わるだろう. Mark Weiser は「最も深遠な技術は消える技術である. それ は，日々の生活の中に見分けがつかなくなるまで織り込まれていく[3]」といっ た。私たちはぺンや蝶番や蛇口を技術とは考えない，それらは単に私たちが当 然亡思う世界の機能であり，世界の中での私達の行動を形作るものである. ᄀ ビキタスコンピューティングによって情報技術を使用することは, パーンナル コンピュータを使うことよりも, こうした日々のオブジェクトの使うことのよ うに感じるようになるだろう.
\end{abstract}

ユビキタスコンピューティングのトレンド は，単に人々の情報へのアクセス方法と使用 方法が変化することだけを意味しているので はない。ユビキタスコンピューティングは 人々のサービスへのアクセス方法と使用方法 に深い影響を及ぼすと考えられ，それは環境 の中に埋め込まれることによってのみ意味を 成す新たなサービスを可能にする。そして, 最終的には，ユビキタスコンピューティング は私たちをユビキタスコマースの世界へ導く だろう。それ故，ユビキタスコンピューティ ングの考察は, 次のようなビジネスの根本的 な問い一向けられる。物理環境がサービスで 満ち溢れた世界においては, 何をもってビジ ネスをするという意味になるのだろうか?

根本的に, ユビキタスコンピューティング はビジネスと顧客が互いにアクセス寸る手段 を変えられるし, 変えていくだろう。これま で，ビジネスにとって顧客にアクセス寸る手 段を獲得することは重要な課題だった。 もし 顧客へのアクセス手段の獲得が問題ではなく
なるとすると，どうなるのだろうか. ユビキ タスコンピューティングの登場によって, ビ ジネスにおいて適切なメッセージを適切な時 間に適切な人へ非常に低いコストで届けるこ とが可能になるのではないのだろうか? だ が, これらの革新的な顧客へのアクセス手段 には全く新しい課題があり, それらは多くの 点においてコストの問題よりもはるかに複雑 である。つまり, 何が適切なメッセージなの か?いつが適切な時なのか? 顧客が人である と分かっているとして, ) だれが適切な人なの か? 単に顧客ヘメッセージを届ける以上に, どんな種類のインタラクションが可能になる のだろうか?この新たな世界において, ビジ ネスはどのようにサービスを展開し, 利用す るのだろうか?ビジネスと顧客の関係はどの ように発展するのだろうか?これらの課題 は，ユビキタスコンピューティングの展望を 完全に実現するためには取り組まなければな らないものであり, また, これらの課題を解 


\section{ユビキタスコンピューティングによって, 場所の役割, サービスの 範囲, 時間と頻度など, 顧客とのインタラクションの特性が変化す る.}

決することは, ビジネス戦略における根本的 な課題になるだろう.

E-ビジネスブームの中，顧客へアクセスす る手段として, ビジネスはインターネットを 使い始めた。これは主に Web サイト上で行わ れており，人々は家庭や仕事場の PC からア クセス寸る.PC や電話以外の製品を通してサ ービスとやりとりするといったユビキタスコ ンピューティングへの変化は, ビジネスと顧 客の関係の本質を完全に変えるだろう。ビジ ネスと顧客の関係をより近いものにしようと 努力すると, サービス内容とインタラクショ ンが過去の形態のままでは不十分であること が分かる．顧客との関係を真剣に考えると， 生活の違う部分における関係を育てるのと同 様の特性を考慮しなければならない。 その特 性とはアウェアネス (認識性), アクセシビリ ティ (アクセス可能性), レスポンス性（反応 性）である.

あなたが誰かとコミュニケーションをとっ たとすると，お互いに相手を十分に認識して いることになる，あなたはお互いの関係がど のようなものであるか, またその関係を変化 させる方法を自然に知っている. 関係が深く なるほど，お互いの認識は強くなる，一方で, 疎遠になればなるほど，関係を維持すること は困難になる，人は完璧にお互いを認識し親 しくなれるが，相手の必要に応じて応答を返 さなければ, その関係は破綻する. 他人とや りとりすることは, 時間, 気力, 期待を込め た信頼の投資であり, その結果適切で望んだ 反応を得られる。この反応は投資なしにはあ りえない。

現在，たいていの CRM アプリケーション は適切な顧客を見分けて対象とすることに力 を注いでいる。ツールは顧客の購買能力の期 待值計算と, 顧客に勧められる製品の決定を 支援する。しかし，いったんあなたが対象と する客層を知ると, 次に何ができるのだろう か? 専門の電話サポート，セルフサービスの Web サイト, 狙い定めた広告, そして現行モ
デルである分類式の勧誘以上に何ができるの か?

Web や電子メール，携帯電話，無線 PDA, ポケットベル, インスタントメッセージ, 協 調作業環境, ビデオ会議, そして情報端末を 含めたユビキタスコンピューティングに関連 した新たな技術によって, 今日の CRM の機 能性を拡張し変化させる方法を考えることが できる，単純に言えば，それらの技術はアウ エアネスを達成する新しい方法, アクセシビ リティのための新しいチャネル, レスポンス 性のための新しい技術を提供する. E911 法に よって, 位置認識型携帯電話が販売されるだ ろう. 同様の可能性は有線の PDAにも見出さ れるだろう。無線認識タグ (RFID) とタグづ け技術はサプライチェーン効果と顧客価值を 増加させる. タグの性能が向上し価格が下が ることによって, アウェアネス, アクセス, 新しい态答方法を備えたさまざまな新しいサ 一ビスが可能になるだろう。他の技術もより 広い用途がある. バイオメトリクスのように， セキュリティ問題をサポートする技術もあ る. バイオメトリクスはさまざまな状況にお いて指紋や声紋, 筆跡鑑定, 顔認証, 手形な どを用いて, 個人の識別や認証を可能にする. ビジネス戦略に与えるインパクトという点で の課題の解決について, 顧客との関係やサー ビスがユビキタスコンピューティングによっ てどのように変化するかを例を挙げて説明す る.

\section{オンラインの薬収納棚}

朝, 洗面所一行く場面を想像してみよう. 歯を磨きながら, 薬棚の鏡を見ていると, 今 日はとても花粉が多いのでアレルギーの薬を 持っていくよう薬棚が注意してくれる. 薬棚 はあなたを識別し, 必要な薬を理解する。薬 を取ろうとして, 誤って別の薬を選しでしま っても, オンライン薬棚は親切に間違いを指 摘してくれ，錠剤がほとんじなくなっていれ ば自動的に補充の注文をしてくれる[2]. 


\section{モバイル召使(Mobile Valet)}

無線通信ができる PDA を持って電気屋に 入る場面を想像してみよう.PDA はあなたの 位置を認識して製品情報や顧客サービス，保 証，支払いなど，買い物に適切なカテゴリの サービスを提示してくれる. PDA を興味のあ るインクジェットプリンタへ向けて, 以前に 便利だと思った製品比較サービスを選ぶと， 製品の比較情報が PDA 上に表示される.あい にく,いらだたしいことに PDA の画面は小さ く，十分な情報を見ることができない。ここ で，モバイル召使を使うことによって，あな たはより詳しい情報を表示できる近くの情報 端末へサービスの対象を変更できる[1]. PDA をプリンタのひとつに向け製品批評を 行う別のサービスを選択すると，その内容が 情報キオスクに表示される. 支払いと保証の オプションの確認もできる．さらに，そのプ リンタはあなたがもっているデジタルカメラ と一緒に使用できるかどうかを個人顧客サー ビスの提供者へ尋㸚ることができる．数分以 内に，店にいた顧客サービスの代理人が，そ の疑問に答えに来てくれる.

どちらの例もユビキタスコンピューティン グによって可能になるビジネスと顧客の関係 における三つの特性（アウェアネス，アクセ ス性，レスポンス性）を示している。これら のサービスは，顧客と顧客のニーズを理解す るものである。これらのサービスは顧客が最 も必要とする時に顧客へアクセスでき, 簡単 かつ自然なアクセス方法を顧客へ提供でき る. サービスは顧客のいる場所で利用可能な 資源を用いて，顧客のニーズに即座に応答す る.これらの例はユビキタスコンピューティ ングによって，場所の役割，サービスの範囲， 時間と頻度など, 顧客とのインタラクション における特性がどのように変化するかも説明 している.

\section{顧客のいる場所がビジネスの場になる.}

技術によって, 顧客のいる場所がサービス 提供者にとってのビジネスの場になる。 これ は電脳空間と物理世界を繋ぐ基本原理であ る. 本屋でバーコードスキャナが付いた携帯 電話を利用して，背表紙のバーコードを読み 取って欲しい本を選び，別の本屋でそれらの 本を買うことができる。これによって携帯電
話はお気に入りのオンライン書店のセルフサ 一ビスの携帯型支払い機になる。しかし，才 ンラインの世界と物理世界を相反するものと みな寸必要はない，私たちの存在する場所と 携帯している物を統合する革新的で新しいチ ヤネルを作り出すことで, 物理世界において あらゆる時に人々に対してビジネスを行える ようになる，オンライン薬棚は，顧客にとっ て適切な場所で直接サービスを行う良い例で ある. オンライン薬棚は, 物理世界での存在 場所の競争における重要性も示している.

\section{製品やサービスが使用される場所に存在 するということはビジネス競争で重要に なるだろう.}

今日, 電子商取引を行う Web サイトは多く のビジネスにとって重要だと考えられてい

る。しかし，そうしたサイトをもっているか らといって, 顧客とのインタラクションの究 極に達しているわけではない，例えば，二つ の薬局について考えてみよう。一つの薬局は 世界で最も大きな電子商取引の Web サイト をもっており，簡単な注文，非常に効率的な 運営，セルフサービスのサポート，注文の追 跡，アドバイス，アカウントの管理，全ての 種類の個人化という特徵をもつものとする. もう一方の薬局はオンライン薬棚としてあな たの洗面所にあるものとする。おそらくあな たはその素晴らしいWeb サイトは利用しな いだろう。それはなぜだろうか?当面のニー ズを察知してくれるサービスに，必要なとき すぐにアクセスできるということは，アクセ ス場所が別の場所にある場合と比較して，全 く異なるインタラクションと，その結果とし ての顧客との関係を可能にする．例えば，数 時間後にラップトップのコンピュータに電子 メールで間違った錠剤を選択したというメッ セージを受け取ったとしても，それは意味が ない.

ビジネスは，顧客が製品やサービスを必要 としている場所に存在していることを必要と するだろう．Web サイトは重要であり, 将来 もそうだろうが，結局は，多くの顧客との接 点のひとつにすぎない. 先程の例はまた, サ 一ビスにとって物理的な存在場所をもつだけ では不十分で, アウェアネス, アクセス, サ イトでのレスポンス性といった要素も非常に 重要であることを示している。受動的な情報 


\section{現在は店内で単なるスクリーンであるものを,さまざまなサービス 提供者が使用できるサービスチャネルへ変化させることが目標で あり, チャンスである.}

端末では, 顧客のニーズを察知しないし, 良 い対応もできない。

\section{モバイルデバイスやモバイル機器は遠隔 のサービス提供者の目や耳となる.}

顧客に関するほとんどの知識は，顧客が今 何をしているかではなく，過去に何をしたの かという履歴に基づいている。このことは， ビジネスは顧客の購買能力の見積もり, 適切 なマーケティング方法やサービスレベルの選 択に，さまざまなデータ分析ツールを適用で きることを意味している。しかし，これらの ツールは任意の時点において，顧客に提供す るサービスや製品を利用可能にすることや改 善することにはほとんど役に立たない. なぜ なら, ビジネスは顧客の現在の状況を知らな いからである。消防署は，次にどこへいくべ きか決定するために，過去の火事の記録を分 析することはしない。彼らは今起こっている ことを知るために，火災報知器を使用する。

モバイルデバイスが，アウェアネスとレス ポンス性を備えるためには，状況センシング のような機能が必要になるだろう。電話や, PDA，その他の専用デバイス（デジタルカメ ラなど）はゆっくりと，しかし着実に，周り の状況を認識するようになるだろう。それら は，まもなく自らの位置を知ることができる ようになるだろう。位置情報は，ユーザのタ スクを指し示す重要な手がかりとなることが 多い。例えば，もしあなたがガソリンスタン ドにいるのなら，たいていはガソリンを買っ ているだろう。もし，あなたが銀行にいるの なら，たいていは銀行口座を利用しているだ ろうし，店にいるのなら買い物をしているだ ろう。その上，もしサービス提供者が特定の 場所についての情報を知っているのなら, そ の場所でどんな資源が利用可能かを推定でき るだろう。例えば，サービス提供者がある場 所で利用可能な製品やサービスの種類，その 場にいる他の人，情報端末などの資源が利用 可能かどうかについて知っていたとしよう。
すると，モバイル召使の例で説明したように， 顧客はモバイルデバイスを興味のある対象へ 向けることで，サービス提供者に情報を送る ことができる。その対象は，顧客の買いたい 製品や，壊れて修理したい家電，売り家に関 する詳しい情報などが考えられる。モバイル デバイスは本質的に世界中でのリモコンであ る.

\section{場所に関連付けられたサービスは人々と 一体になる.}

遠隔サービスが競争で優位に立つために は，顧客のいる場所で利用可能な資源を最大 限に活用しなければならない。モバイル召使 のシナリオでは，顧客がサービス提供者にア クセスし，いくつかの競合する売り手につい て支払いと保証のオプションを比較した。モ バイルデバイスによって本質的に，顧客は多 数のサービス提供者にアクセスして情報を取 得できるようになる。ビジネスはもはや，顧 客の無知を食い物にすることはできない，ビ ジネスはもはや，他の誰かのほうが安い值段 で売っているという事実を隠すことはできな い.しかし，もし顧客があなたの店にいるの なら，顧客の要求に合わせて值段を変更した り，他の方法で良い取引をするための，最適 の場所にいることになる.

顧客が利用中のサービス提供者と協力する ことで，ビジネスはさらに迅速で効率的なサ 一ビスを提供できる。遠隔のサービス提供者 は深刻な制限に直面している。彼らは，結局 は遠隔にすぎない. 彼らにはたいていの場合， 現地スタッフがいないため, 提供するサービ スの性質が大きく制限されてしまう。しかし， 遠隔のサービス提供者は，現地のスタッフと 協調することでよりよいサービスを提供する ことができ，これは双方にとって利益になる． 遠隔の顧客サービス提供者は，モバイル召使 を利用して, 顧客が興味をもっているモデル， 欲しがっているアクセサリ，関心事項を現地 の店舗に知らせることができる。その結果， 
店は，適切なサービスを提供する人を選択し， 詳細な手助けをしてくれる良い場所になる. そして販売機会を増やし, 顧客を満足させら れる。これは, 現地のスタッフが遠隔の顧客 に匿名で接近するより, 特定の顧客のニーズ を理解して具体的に応対寸る機会を提供する 方が，豊かなインタラクションになるという ことを示している．特定の場所から顧客サー ビスなどの特定の機能を分離することで，特 定の要求をサポートするために場所を越えて 働く，個人のサービス提供者などの新しいサ 一ビス（融資，保険，技術支援，旅行など） が可能となる. これは特定の製品一つや挿話 に基づいた関係とは異なる種類の顧客関係を 表わしている.

\section{サービスはできる限り最良のサービスを 提供するために顧客の位置情報を活用す るだろう。}

今日のモバイル市場には, 膨大な量の誇大 広告がある。しかし，そのすべてを顧客に伝 えられるとすると, 現在のモバイル市場の競 争は, あらゆる時間に電話や PDA など, 顧客 にとって最も表示してほしくない画面へサー ビスを届けるという競争になる。このことに よって多くのサービスのモバイル市場の広範 囲な普及が妨げられる。モバイル召使は，顧 客がいる場所の資源を組み合わせて利用する ことで, それらの制限を乗り越えてサービス を届けるというアプローチを表わしている.

もしも, 電話機が部屋の中で最も貧弱な画面 であれば，おそらく，近くにある別のもっと 良い画面を利用できるだろう。この技術によ って，まず顧客の状況を把握し，顧客のモバ イルデバイスや近くの画面, 音響システム, 情報端末，(RFID タグをつけた）スタッフを 含めた利用可能なサービスチャネルを特定 し, それらのチャネルを用いて最良のサービ スを提供することで, 遠隔のサービス要求に 対寸る迅速な応対が可能になる。これは実現 可能である，なぜなら，私たちがいる場所は 顧客が要求を達成することを望み，それゆえ 資源を利用可能にしようと思うべきだからで ある. 現在は店内で単なるスクリーンである ものを, さまざまなサービス提供者が使用で きるサービスチャネルへ変化させることが目 標であり，チャンスである.

\section{サービス提供者は彼らの顧客に対して常 に注意を払わなければならない.}

私たちは一般的に医療を年に数回利用する サービスとして考えている。しかし，オンラ インの薬棚のような専用のサービス機器を用 いることで, 毎回洗面所へ行くことが健康管 理サービス提供者への訪問になる可能性があ る。モバイル召使サービスは顧客がいる場所 やニーズを知るために, 常に電源が入ってい るべきであり，このアウェアネスによってあ らゆる種類のサービスを可能にする. 現在ど れだけの企業がこのレベルの顧客への配慮を 行えるのだろうか.

\section{サービス提供者は顧客とのインタラクシ ヨンにおいて，十分に選択的で正確でな ければならなくなるだろう.}

私たちは家の自動温度調節器を使用する際 はほとんどその調節をしない. 同様に, オン ラインの薬箱は, たまにちょっとインタラク ションをとるだけで，ほとんどの場合何も言 ってこないだろう。このように，サービス提 供者と私たちの間では, 検査のような長時間 の激しいインタラクションをたまにとるので はなく, “マイクロサービス”のような短いイ ンタラクションが頻繁に起こるようになるこ とが重要である。この世界では，私たちはほ とんど常にサービス提供者と会話をする. 事 実, 多くの場合, 数え切れないマイクロサー ビスを利用するか，それとも使いきりにする かを決定することは難しくなるだろう。その 結果は, 実際に製品やサービスを構成する物, それらの認知方法, 顧客に提供される価值の 基本的な変化となって現れる.

\section{もし，私たちがプライバシーを重視する なら，プライバシーを商売にする者が出 てくるだろう.}

顧客の関係を認識し迅速に応対するために は, 現在の顧客の状況へアクセス寸ると同時 に顧客についての大量の知識が要求される. この必要性は, 個人情報をサービス提供者に 提供する必要性を生み出す. 洗面所のセンサ やあなたの毎日の行動を遠隔のサービス提供 者へ報告するモバイルデバイスの想定シナリ オは，自然とプライバシーに対する重大な懸 念を生み出す. 私たちは, 自分たちのプライ バシーへの劦威が非常に現実的な問題である 
ことについては同意するが，プライバシーが 即座になくなってしまうという話をすると大 げさだと言う。

プライバシーがますます重要になる一方 で, この重要性が示しているのは, プライバ シーが先ほど挙げた種類のサービスの実現に おける克服できない障害であるということよ りも，むしろ新しいプライバシー管理サービ スというビジネスの機会があることである.

既にこの分野には, 安全な電子メールを可能 にする暗号化技術，プライバシーの指針に従 つて企業の承諾を認証するプライバシ一監査 サービス, 盗聴を防止する電話サービスなど, さまざまな製品とサービスが存在している. それでもやはり, 顧客の関係を広げることに よってビジネス機会を調査することを望んで いるビジネスは, 彼らが集めた情報について, 誰が共有するのか，どのように使用するのか を, 注意深く考えなければならない。個人情 報の使用における社会的な承認は, 詳細まで 明確に理解できる方法で個人情報の収集と使 用を行い，不可欠なサービスとして成長する ことで得られるだろう。医者が診察中にシャ ツを脱ぐよう言ったとき, それがプライバシ 一の侵害とは受け止められない。もしも，不 動産業者が言えば, それは深刻な問題である。 もちろん, これらの例において調查時の役割 が違うということを私たちは理解している. プライバシーの問題は, 技術, 法律, ビジネ ス戦略を組み合わせることで解決できるだろ う。

\section{顧客が人である必要はなくなるだろう.}

私たちの周りの物がもつと知的になれば, 判断を下寸能力がつき, 自ら行動するように なるだろう。 その時点で, 生命のない物が顧 客になるだろう。おもちやの精巧さの進歩に ついて考えてみる. 現在, 人気がある娛楽口 ボットは印象的な振る舞いをみせる。私たち はロボットに新たな振る舞いを与えたが，こ れまでロボットはビジネス的な振る舞いを身 につけたことはあっただろうか? そうした可 能性を実証するため，実際にお金をもち，そ の使用法を理解する人形のプロトタイプを開 発してきた。 その人形は，他の人形がつけて いるのを「見て」, それから「欲しい」アクセ サリを選択し注文する。
買い物に行く人形の例はどちらかといえば 非現実的で想像しにくいかもしれないが，私 たちはすでに物がビジネス的な選択を行う例 を知っている．例えば，サーモスタットはこ の冬にあなたの家を暖かくするためにあなた に多くの金をかけさせるだろう。もし，単に 望みの温度を言うのではなく，最もお金をか けたい物が通信を行って，与えられた予算の 中でサービス提供者と可能な限り最良の取引 をさせ，家を暖めさせるとどうなるのか?た いていの場合, 私たちが使っている物は私た ちより良い決定を行える，例えば，あなたの 車の次の整備費をどのようにかけるのが良い か，あなたとあなたの車のどちらがより知っ ているだろうか?いったん物が顧客になる と, 何が顧客関係を構成しているのかという 疑問を完全に再調査寸るべきである。どのよ うにして車と商売をするのだろうか? どのよ うにして, 家にサービス提供者を変更させる のだろうか? どのようにして人形からひいき にしてもらうのだろうか?それらはこの先ユ ビキタスビジネスがもたらすと考えられる課 題である.

\section{まとめ}

ユビキタスコンピューティングによりビジ ネスでは顧客との関係の重要な捉え方を再定 義しなければならなくなる. ビジネスは常に 顧客のニーズを知り, サービスへのより自然 で強力なアクセス手段を提供できるようにな る. センサや現地の資源を使って, さらに機 敏に顧客に対応できるようになる。それらの 新しい可能性は, 競争の目標をも示している. どのようにしてサービスを，あなたの製品が 使われたり購入されるあらゆる場所に広げる のか? どのようにして顧客のニーズを知るの か?どのようにしてそれぞれの場所にある全 ての資源を利用するのか? どのようにして， 顧客のプライバシーを侵害寸ることなく選択 的で正確な顧客インタラクションを実現する のか?これらの課題はユビキタスビジネスで の競争社会を定義するだろう.

\section{文献}

1. Fano, A.E. What are a location's "File" and "Edit" menus? Journal of Personal and Ubiquitous Computing 5, 1 (Jan. 2001). 
2. Wan, D. Magic medicine cabinet: A Andrew

Fano situated portal for healthcare. In Proceedings of International Symposium on Handheld and Ubiquitous Computing (HUC'99). Karlsruhe, Germany, 1999.

3. Weiser, M. The computer for the $21^{\text {st }}$ Century. Sci. Am. 265, 3 (Sept. 1991), 94-104.

（andrew.e.fano@accenture.com）ははイ リノイ州シカゴにあるアクセンチュア技術 研究所の主任研究員である.

\section{Anatole}

Gershman

( anatole.v.gershman@accenture.com )

は，イリノイ州シカゴにあるアクセンチュ

ア技術研究所の研究所長である.

訳 : 庄司武（大阪大学・情報科学研究科） 